\title{
Erratum to: Fugong virus, a novel hantavirus harbored by the small oriental vole (Eothenomys eleusis) in China
}

Xing-Yi Ge1, Wei-Hong Yang ${ }^{2}$, Hong Pan², Ji-Hua Zhou², Xi Han², Guang-Jian Zhu ${ }^{3}$, James S. Desmond ${ }^{3}$, Peter Daszak ${ }^{3}$, Zheng-Li Shi ${ }^{1}$ and Yun-Zhi Zhang ${ }^{2^{*}}$

\section{Erratum}

Unfortunately, the original version of this article [1] contained an error. After publication it was noticed there was a missing acknowledgement. The end of the acknowledgment section should have stated the work was also jointly funded by the USAID Emerging Pandemic Threats (EPT) PREDICT program.

\begin{abstract}
Author details
'Key Laboratory of Special Pathogens, Wuhan Institute of Virology, Chinese Academy of Sciences, Wuhan 430071, China. ${ }^{2}$ Yunnan Provincial Key Laboratory for Zoonosis Control and Prevention, Yunnan Institute of Endemic Diseases Control and Prevention, Dali 671000, China. ${ }^{3}$ EcoHealth Alliance, New York, NY 10001, USA.
\end{abstract}

Received: 25 April 2016 Accepted: 25 April 2016

Published online: 05 May 2016

\section{References}

1. Ge X-Y, Yang W-H, Pan H, Zhou J-H, Han X, Zhu G-J, Desmond JS, Daszak P. Shi Z-L, Zhang Y-Z. Fugong virus, a novel hantavirus harbored by the small oriental vole (Eothenomys eleusis) in China. Virol J. 2016;13:27.

\footnotetext{
* Correspondence: zhangyunzhi1818@163.com

${ }^{2}$ Yunnan Provincial Key Laboratory for Zoonosis Control and Prevention, Yunnan Institute of Endemic Diseases Control and Prevention, Dali 671000, China

Full list of author information is available at the end of the article
}

Submit your next manuscript to BioMed Central and we will help you at every step:

- We accept pre-submission inquiries

- Our selector tool helps you to find the most relevant journal

- We provide round the clock customer support

- Convenient online submission

- Thorough peer review

- Inclusion in PubMed and all major indexing services

- Maximum visibility for your research

Submit your manuscript at www.biomedcentral.com/submit 